\begin{tabular}{|l|l|l|l|}
\hline Received Jun 12, 201x & Published Aug 26, 201x \\
\hline
\end{tabular}

\title{
Strategy Guidance and Counseling Comprehensive Based Spiritual Intelligence for Student in the Digital Era
}

\author{
${ }^{1}$ Caraka Putra Bhakti, ${ }^{2}$ Fuad Aminur Rahman, ${ }^{3}$ Muhammad Alfarizqi Nizamuddin Ghiffari \\ Email : caraka.pb@bk.uad.ac.id ${ }^{1}$, fuad1400001182@webmail.uad.ac.id ${ }^{2}$ \\ muhammad1500001138@webmail.uad.ac.id ${ }^{1}$
}

${ }^{1}$ Universitas Ahmad Dahlan, Yogyakarta, Indonesia

${ }^{2}$ State Senior High School 1 of Cihara, Indonesia

\section{ABSTRACT}

The purpose of this paper is to discuss strategy guidance and counseling comprehensive based on spiritual intelligence for students in the digital age. Guidance and counseling comprehensive is part of education, which is also a model of guidance and counseling that adheres to the principle of developmental guidance and counseling. The basic assumption of the Guidance and development counseling approach is the idea that healthy individual development will occur in the healthy interactions of individuals with their environment. In other words, the environment for individuals becomes a learning environment, because there is various intelligence that needs to be considered in the process of individual development and spiritual intelligence is one aspect of individual development that needs attention. Spiritual intelligence is the highest form of intelligence that combines the two previous forms of intelligence, namely intellectual intelligence and emotional intelligence. Spiritual intelligence is considered as the highest intelligence because it is closely related to people's awareness to be able to interpret everything and is a way to be able to feel happiness. Especially in the digital era, the era illustrates that the technological revolution phase has changed the way and human behavior in scale, scope, complexity, and transformation from previous life experiences, requires that every individual must have good spiritual intelligence so that they can face the development of the digital era this dynamic well.

\section{INTRODUCTION}

Special developments in the digital era that continue to move quickly and dynamically need to be addressed wisely by all parties involved in the world of education, namely by always up to date in resolving changes, whether, in the form of systems, models, or strategies used. Because the primary purpose of education is to form a complete human being. The whole human intends to foster humans from various aspects not only intellectual elements but also emotional and spiritual elements. But in reality at this time education prioritizes intellectual aspects as a measure of the success of an education. 
The teacher as one of the human resources has an important role in determining the vision, mission, and objectives of the education process. As the most important resource in an educational process, teachers are also people who fill educational institutions with their work, talent, and creativity. Guidance and Counseling Teachers who are also one of the parties involved in the world of education must continue to upgrade their competencies and abilities in providing comprehensive Guidance and Counseling services in schools, especially in the current digital era. because life paradigm in the global era of challenges to life has the competence to develop their lives effectively, productively, beneficial and helpful, and their environment has high quality (Caraka et al., 2016).

The skills and strategies of the guidance and counseling teacher in providing guidance and counseling services also need to get full attention, thus making the process of guidance and counseling services more meaningful. In the sense of service that helps students from various aspects such as intellectual aspects, emotional aspects, and spiritual aspects, which aims to enable students to understand, accept, direct, make decisions, and realize their decisions responsibly.

However, departing from reality in the field, there are still some counseling guidance teachers in schools who only focus on the content of services only for intellectual aspects, because of several factors, such as understanding counseling guidance teachers who are less related to understanding other aspects such as spiritual aspects and demands of the times only focused on intellectuals. Of course, this makes guidance and counseling services less concentrated on the development of students' spiritual aspects. Based on data reported by KPAI, stated that the number of educational cases as of May 30, 2018, amounted to 161 cases, as for the details; 23 child victims of brawl or 14.3 percent, 31 cases of brawl children or 19.3 percent, 36 victims of violence and bullying, or 22.4 percent, 41 cases of violence and bullying, or 25.5 percent (Widiastuti, 2019). One of the factors causing the emergence of cases in the world of education is because there are still some students who do not have spiritual aspects, especially good spiritual intelligence.

Based on the above, the development of a comprehensive guidance and counseling service strategy based on spiritual intelligence is very necessary. Spiritual intelligence itself is the highest form of intelligence that combines the two previous forms of intelligence, namely intellectual intelligence and emotional intelligence. Spiritual intelligence is considered as the highest intelligence because it is closely related to people's awareness to be able to interpret everything and is a way to be able to feel happiness. Spiritual intelligence also has a good influence on students in school, referring to research conducted by Basuki stated that there is a significant direct effect between spiritual intelligence on learning motivation (Basuki, 2015).

The above explanation is the main basis for the author to form an idea that is in the form of a comprehensive guidance and counseling service strategy based on spiritual intelligence for students in the digital era. This strategy is a strategy that focuses on the spiritual development of individuals, especially students in achieving the development of good spiritual aspects, so as to make it as a person 
who is able to have spiritual intelligence well, understand themselves, the environment and be able to be responsible independently with decisions that have been taken, too able to face the development of the digital age today more wisely. This paper itself is a literature study that discusses the underlying problems in this research theme. So that the data analysis is done by using argumentative descriptive as an effort to provide interpretation and solutions to the problems discussed.

\section{DISCUSSION}

\section{Concept of Spiritual Intelligence}

During this time, the term intelligence is often connoted with intellectual intelligence alone or commonly known as IQ (Intelligence Quotient). But at this time, the assumption that human intelligence is only based on intellectual dimensions is no longer relevant. In addition to intellectual intelligence, humans also still have other intelligence dimensions including emotional intelligence (EQ) and spiritual intelligence (SQ) (Yosef, 2005). The potential for intelligence is now being talked about by people, namely spiritual intelligence (Saifullah, 2005). Intelligence is also an abstract picture filtered from behavioral observation in a variety of circumstances or a hypothesis construction and can only be predicted from signs of behavior. So, however, intelligence has something to do with the ability to capture abstract and complex relationships, as well as problem-solving abilities and learning from experience (Maramis, 2006).

According to experts, there is a lot of intelligence given by God to humans. One of them is spiritual intelligence (SQ). Spiritual intelligence (SQ) which is closely related to the issue of meaning and value was first conceived and discovered by Danah Zohar and Ian Marshall. According to Zohar and Marshall explained that spiritual intelligence in terminology is a basic intelligence with which it can solve problems of meaning and value, place actions or a way of life in a broader, richer, and meaningful context (Siswanto, 2012). Spiritual Intelligence is defined as the ability to apply spiritual resources and qualities to enhance daily functioning and wellbeing (Amram, 2007).

Sinetar and Khavari also explained that spiritual intelligence is a mind that gets inspiration, encouragement, and effectiveness that is inspired by the appreciation of God where we become part of it (Suyanto, 2006). True spiritual intelligence is intelligence to deal with and solve problems of meaning and value, not only to humans but also before God. Basuki also stated that in the last decade there emerged a spiritual intelligence which was believed to be the culmination of intelligence because it not only relied on reasoning and emotion but also emphasized the spiritual aspect in directing people towards success in living life (Basuki, 2015)

Based on the explanation above, it can be concluded that spiritual intelligence is a form of intelligence or thought by which an individual can deal with problems or solve a problem faced with more meaningful and broad, because it does not only rely on reason or emotion alone but also relies on spiritual aspects who try to deliver the individual to succeed in carrying out the life faced. 


\section{Concept of Guidance and Counseling Comprehensive}

The concept of "Development Guidance and Counseling" which is juxtaposed with the concept of "Comprehensive Approach" is taken from Robert D. Myrick's concept of "Developmental Guidance and Counseling: A Comprehensive Approach" which means that developmental counseling guidance is a comprehensive approach (Myrick, 2011). Guidance and development counseling can also be interpreted as perspectives, approaches in guidance and counseling that are based on developmental theories and aim at developing individuals towards optimal development in a supportive development environment (Bhakti, 2015).

According to Sutoyo, et all. (2015) stated that comprehensive guidance and counseling is a paradigm of thinking in guidance and counseling that the development of the focus is to help "development of potential" individuals according to their characteristics and "needs". Because the individual's potential is diverse and the scope is quite large, all of them need to be developed comprehensively, so that it is not enough to help develop it if only done by school counselors, but collaboration with various parties that can contribute to the development of individual potential. It is also a concept of guidance and counseling services reflecting approaches to the foundation of programs, service systems, management, and accountability.

Uman Suherman emphasized that comprehensive guidance is also a current view that starts from positive assumptions about human potential. Based on this assumption guidance is seen as a process of facilitating development which emphasizes efforts to help all students in all phases of its development (Suherman, 2011). Comprehensive guidance and counseling also have a component that includes the activities and responsibilities of all those involved in a comprehensive guidance and counseling program (Cobia, D. C and Henderson, D. A., 2009).

The concept of comprehensive Guidance and counseling is strengthened by the 2013 curriculum and the Minister of Education and Culture Regulation No. 111 of 2014 concerning Guidance and Counseling in Primary and Secondary Education. In the regulation it strengthens the role of counselors as guidance and counseling teachers need to collaborate with school stakeholders in developing the potential and competence of students based on student needs.

Based on the explanation above, it can be concluded that the concept of Guidance and comprehensive counseling is a view or paradigm in guidance and counseling services that have the main focus and objectives in developing the potential of students in accordance with the characteristics or needs through collaboration with related parties, as well as reflecting approach to program foundation, service systems, management, and accountability. 


\section{Implementation of Strategy Guidance and Counseling Comprehensive Based Spiritual Intelligence for Student}

The digital age is another term from the era of disruption or the era of industrial revolution 4.0. The era of industry 4.0 as a technological revolution phase changed the way human activities in scale, scope, complexity, and transformation from previous life experiences (Yahya, 2018). Humans will even live in global uncertainty, therefore humans must have the ability to predict a rapidly changing future. Each country must respond to these changes in an integrated and comprehensive manner. The response involved all global political stakeholders, ranging from the public, private sector, academia, to civil society, so that the challenges of industry 4.0 could be managed as opportunities.

The challenges faced in this digital era need to pay attention to several main aspects, especially the spiritual aspects or individual spiritual intelligence. As a service that focuses on the development of the potential of individuals or students according to their characteristics and needs, comprehensive guidance and counseling services certainly need to take the right attitude in seeing this dynamic development. Therefore the implementation of strategic guidance and counseling comprehensive based spiritual intelligence is a must for school counselors in schools, and collaboration between counseling guidance teachers and stakeholders or parties suspected of being able to support the development of potential students, especially spiritual aspects, is the underlying assumption in developing this strategy.

Collaboration between school stakeholders to develop students' spiritual competencies is important. Stakeholders are the spearhead of education in realizing educational goals to deliver students to have spiritual competence. Therefore, the following are strategies for comprehensive guidance and counseling services based on spiritual intelligence that can be carried out by counselors or counselors in building collaboration with related parties or stakeholders (Sutoyo, A and Dhanianto, I, 2014)

Table 1. Collaboration counseling guidance teacher with Related Parties Or Stakeholders

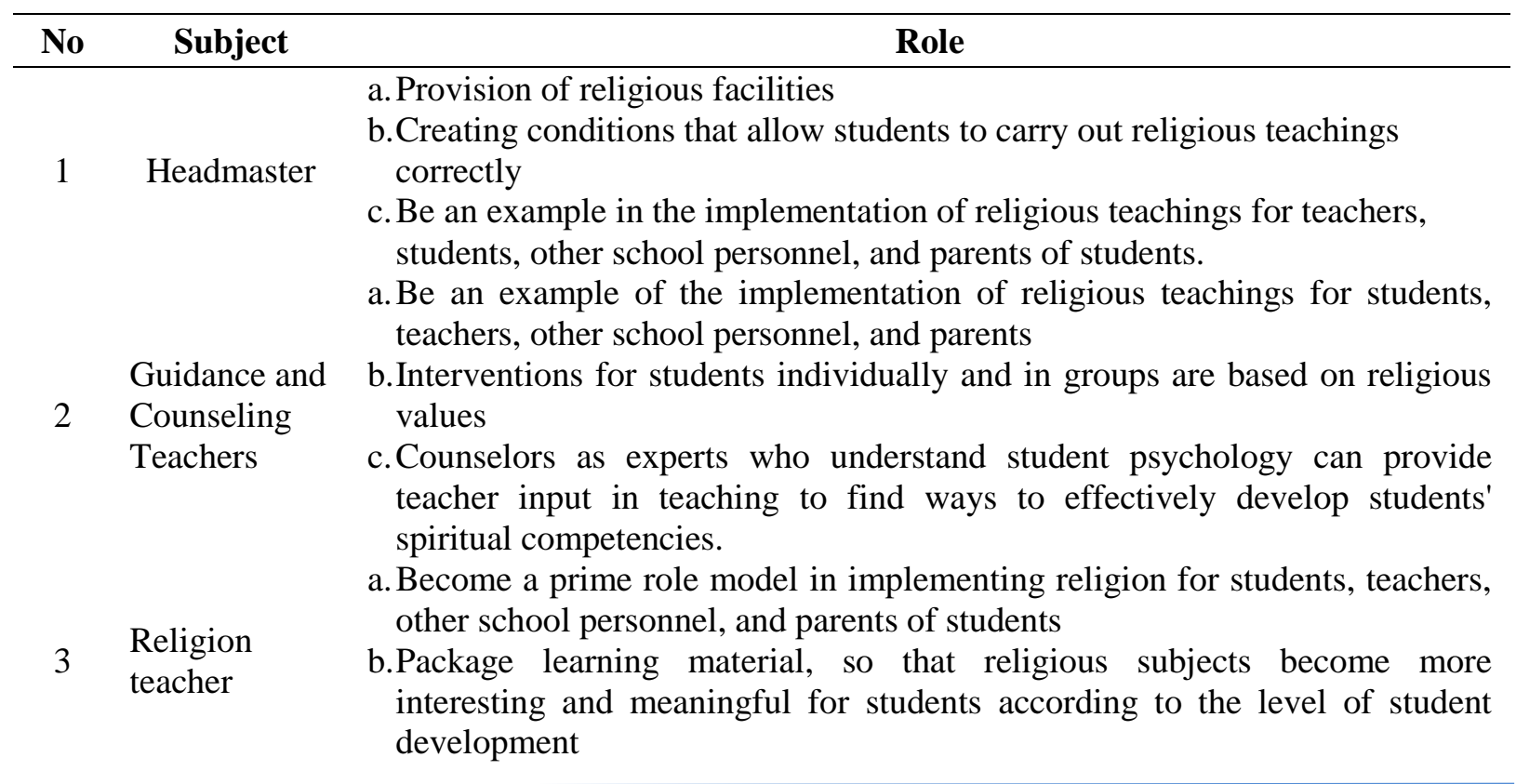


c. Collaboration with teacher subjects about religious values contained in teaching material.

a. Carry out its role as advisor to students, especially in class, which is their responsibility.

b.Help provide opportunities and conveniences for students, especially in class, which is their responsibility to participate in activities in an effort to develop students' spiritual competencies.

c. Become a role model in implementing religion for students, teachers, other school personnel, and parents of students.

a. Linking spiritual values to the lessons taught so that students have a positive appreciation of spiritual values

b.Become a prime role model in implementing religion for students, teachers, other school personnel, and parents of students

$5 \quad \begin{array}{ll}\text { Subject } \\ \text { Teachers }\end{array}$

c. Providing information to the guidance and counseling teacher about various things such as student behavior and needs

d.d. Providing support for services to develop students' spiritual competencies such as giving advice to students not to deviate.

a.Provide support for school policies relating to the development of students'

School spiritual competencies

6 Committee

b.Utilization of society such as accepting schools with pleasure, sharing experiences with students to behave according to religious teachings.

a. Be an example for their children

b.Provide support for guidance and counseling programs to develop student competencies

Parents of

c. Familiarize spiritual values in everyday life in relation to personal, family and society

d.Providing worship facilities and infrastructure at home.

The development of a comprehensive spiritual intelligence-based guidance and counseling service strategy is inseparable from the foundation of programs, service systems, management, and accountability. Therefore, the following are the seven main dimensions of implication in a strategy of guidance and comprehensive counseling based on spiritual intelligence.

The seven main dimensions in the concept of spiritual intelligence are quoted from The Seven Dimensions of Spiritual Intelligence: An Ecumenical, Grounded Theory by Amran, Y in 2007 stated that 7 major themes of SI (Spiritual Intelligence emerged as nearly universal across the traditions and participants. They are: (a) Consciousness: Developed refined awareness and self-knowledge; (b) Grace: Living in alignment with the sacred manifesting love for and trust in life; (c) Meaning: Experiencing significance in daily activities through a sense of purpose and a call for service, including in the face of pain and suffering; (d) Transcendence: Going beyond the separate egoic self into an interconnected wholeness; (e) Truth: Living in open acceptance, curiosity, and love for all creation (all that is); (f) Peaceful surrender to Self (Truth, God, Absolute, true nature); and (g) Inner-Directedness: innerfreedom aligned in responsible wise action. For more details, can be seen in Table II below: 
Table II. The Seven Dimensions of Spiritual Intelligence

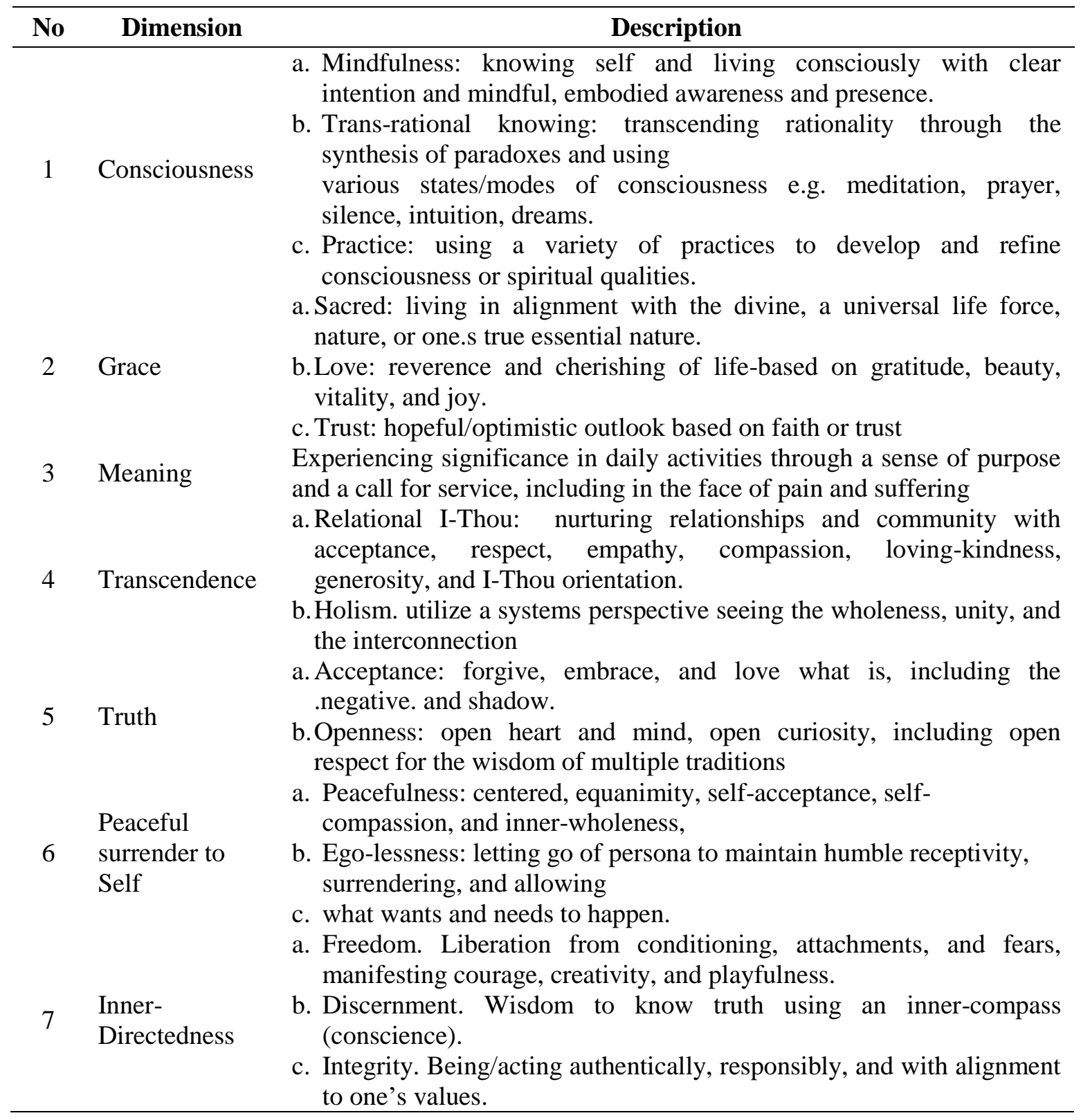

The above explanation provides an overview of the strategy of guidance services and comprehensive counseling based on spiritual intelligence. Detailed guidance and counseling services are also able to contribute positively to each phase of individual development, especially students. The above statement is reinforced by the results of research conducted by Norman C. Gysbrers who explained that:

"research has demonstrated that, when middle school counselor has time, the structure of comprehensive guidance program in which to work, they contribute to positive academic, personal-social, and career development as well as the development positive and safe learning climates in school" (Nurihsan, 2011). 
The effectiveness of comprehensive guidance programs in improving the quality of education has also been studied by Richard Lapan, Norman Gysbers, and Sun as a result of their research:

“...the implementation of a Comprehensive Developmental Guidance Program will result in educational benefits including increased student achievement, more equitable service to student, broader impact on student development and career decision-making, student satisfaction with the relevance of their education, and the development of a safe, orderly, connected school climate" (Timberlane Regional District, 2008).

The basic assumptions of this strategy are also based on an indicator of the success of studies to achieve higher education, namely: (1) Student retention; (2) Educational achievement; (3) Progress of students; (4) Holistic development. In the development of students being "the whole person" is marked by: (a) Intellectual development: develop skills to acquire and communicate knowledge, know how to learn, and how to think deeply; (b) Emotion Development: develop skills to understand, control, and express emotions; (c) Social Development: improving quality in interpersonal relationships, leadership skills, and involvement in society; (d) Development of ethical values: formulate a clear value system that can lead to life choices and can show personal character; (e) Physical Development: obtaining knowledge about the human body and can apply how to prevent disease, maintain health, and improve self productivity; (f) Spiritual development: the search for self-meaning, the purpose of human existence, and questions about the meaning of life (Cuseo, J, 2007).

\section{CONCLUSION}

Based on the explanation above, it can be concluded that collaboration in guidance and counseling is a collaborative activity between the counseling guidance teacher/ counselor and a number of related parties in order to achieve the objectives of the guidance and counseling services program (Nugraha and Rahman, 2017), and developmental tasks are formulated as competency standards to be achieved by counselors, so this approach is also called standard-based guidance and counseling. The standard of student competence in Indonesia refers to the Standards of Independence Competence Learners (SKKPD). Procedures in the preparation of comprehensive guidance and counseling programs are planning, organizing, implementing, and evaluating (Bhakti, 2017). Therefore the strategy of comprehensive guidance and counseling services based on spiritual intelligence is a new paradigm in building students who have good spiritual intelligence, so that the development of this increasingly dynamic digital era can be dealt with wiser, so that the developmental phase faced by students can be appropriate with the times. 


\section{REFERENCES}

Amram, Y. (2007). The seven dimensions of spiritual intelligence: An ecumenical, grounded theory. In 115th Annual Conference of the American Psychological Association, San Francisco, CA (pp. 17-20).

Basuki, K. H. (2015). Pengaruh kecerdasan spiritual dan motivasi belajar terhadap prestasi belajar matematika. Formatif: Jurnal Ilmiah Pendidikan MIPA, 5(2).

Bhakti, C. P. (2015). Bimbingan Dan Konseling Komprehensif: Dari Paradigma Menuju Aksi. Jurnal Fokus Konseling, 1(2).

Bhakti, C. P. (2017). Program bimbingan dan konseling komprehensif untuk mengembangkan standar kompetensi siswa. Jurnal Konseling Andi Matappa, 1(2), 131-132.

Bhakti, C. P.., et al (2016). Improving Quality Of Education Through Collaboration System In The Perspective Of Comprehensive Guidance And Counseling, in International Conference Proceedings 2nd Icet Improving The Quality Of Education And Training Through Strengthening Networking. http://eprints.uad.ac.id/6374/

Cuseo, J. (2007) Student Success: Definition, outcomes, principles, and practices. Esource for College Transitions. 1-16.

Cobia, D. C., and Henderson, D. A. (2009). Developing An Effective and Accountable School Counseling Program. Second Edition. Upper Saddle River, New Jersey, Columbus, Ohio: Pearson Merrill Prentice Hall.

Maramis, W.P. (2006). Ilmu Perilaku Dalam Pelayanan Kesehatan. Surabaya: Airlangga University Press

Myrick, Robert D (2011). Developmental Guidance and Counseling: A Practical Approach Fifth edition. Minneapolis: Educational Media Corporation.

Nugraha, A., and Rahman, F. A. (2017). Strategi Kolaborasi Orangtua Dengan Konselor Dalam Mengembangkan Sukses Studi Siswa. Jurnal Konseling Gusjigang, 3(1).

Nurihsan, Juntika (2011). Membangun Peradaban Bangsa Indonesia Melalui Pendidikan Dan Bimbingan Komprehensif Yang Bermutu. Pidato Pengukuhan Jabatan Guru Besar. Bandung: UPI.

Saifullah. (2005). Psikologi Perkembangn dan Pendidikan. Bandung: CV Pustaka Setia.

Siswanto, W. (2012). Membentuk Kecerdasan Spiritual Anak. Jakarta Amzah.

Suyanto. (2006). 15 Rahasia Mengubah Kegagalan Menjadi Kesuksesan dengan SQ Kecerdasan Spiritual: Yogyakarta: Andi.

Sutoyo, et al. (2015). Bimbingan dan Konseling Perkembangan. Semarang: Program Studi Bimbingan dan Konseling Program Pascasarjana, Universitas Negeri Semarang.

Suherman. U. (2011). Pembangun Karakter dan Budaya Bangsa Melalui Bimbingan Komprehensif Berbasis Nilai Alquran (Tinjauan Filosofis tentang Hakikat dan Peran Manusia). Pidato Pengukuhan Jabatan Guru Besar. Bandung: UPI.

Sutoyo, A. and Dhanianto, I. (2014). The development of student spiritual competency in secondary school through a comprehensive guidance and counseling program. International Counseling Conference and Work, 13-15 Sep 2014, Medan.

Timberlane Regional District. (2008). Comprehensive Guidance Plan. https://public.timberlane.net/curr/parent/Curriculum\%20Plans/Comprehensive\%20Guidance\%2 OPlan.pdf (accessed 21 April 2019).

Widiastuti, R. (2019). Hari Anak Nasional, KPAI Catat Kasus Bullying Paling Banyak" https://nasional.tempo.co/read/1109584/hari-anak-nasional-kpai-catat-kasus-bullying-paling-

banyak, accessed 21 April 2019

Yahya, M. (2018). Era Industri 4.0: Tantangan dan Peluang Perkembangan Pendidikan Kejuruan Indonesia. Naskah Pidato Pengukuhan Guru Besar, Disampaikan pada Sidang Terbuka Luar 
Biasa Senat Universitas Negeri Makassar Tanggal, 14 Maret 2018.

Yosep, I. (2005). Pentingnya ESQ (emosional \& spiritual quotion) bagi Perawat dalam Manajemen Konflik. Disampaikan pada Cerdas, Kreatif, Berwawasan Dan Mandiri (Cerebri) Kegiatan Penerimaan Mahasiswa Baru Fakultas Ilmu Keperawatan UNPAD: Bandung. 